\title{
Livestock grazing impacts on interrill erosion in Pakistan
}

\author{
F. BARI, M.K. WOOD, AND L. MURRAY
}

Authors are former graduate student and professor, Department of Animal and Range Sciences, and associate professor. Deparme'm Experimental Statistics, New Mexico State University, Las Cruces 88003.

\begin{abstract}
This study was conducted for 2 consecutive growing seasons in a temperate region of Pakistan to determine a residual phytomass level necessary to adequately protect the soil against accelerated interill erosion. $A$ rainfall simulator was used to apply rainfall to 48 ( $1 \mathrm{~m}$ square) circular plots arranged in a completely randomized experimental design, with 4 residual phytomass levels and 2 replications. The residual treatment with $3,024 \mathrm{~kg} \mathrm{ha}^{-1}$ phytomass resulted in the lowest erosion rates, and the treatment with $624 \mathrm{~kg} \mathrm{ha}^{-1}$ phytomass produced the highest erosion. Standing phytomass was the most important variable affecting erosion with foliar cover and basal cover also highly correlated to erosion.
\end{abstract}

Key Words: standing phytomass, litter phytomass, foliar cover, sediment concentration, total sediment loss

Rangelands occupy $68 \%$ of Pakistan, and the prosperity of its people is intimately linked with the proper use of these lands for livestock production and as watersheds.

The Tarbela Dam on the Indus River serves as a national asset to meet the water and power requirements of the country. Because of the erosive upstream watershed that could reduce the reservoir's useful life, it is important to determine proper livestock grazing for the watershed. Because of the watershed's steep slopes, high precipitation and improper land use, erosion rates are high. Land managers have little control over topography and precipitation, but potentially have much control on Jand use.

Livestock grazing influences on erosion lave long been a topic of interest. Most research to determine the effects of grazing utilization on erosion has been conducted in the United States. Proper livestock grazing is based on controlling the timing, intensity, frequency, and selectivity of grazing animals (Stoddart et al. 1975). Generally, intensity is recognized as the most critical. Intensity determines the amount of vegetation that remains to maintain the plant, soil, hydrologic, and wildlife components of range ecosystems.

Grazing influences erosion primarily through its impacts on soil and vegetation. Heavy grazing generally increases erosion

Approved for publication by the Director of New Mexico State University Agricultural Experiment Station.

Manuscript accepted 10 Sept. 1994.
(Dunford 1949, Johnston 1962). Vegetation and mulch cover protect the soil surface from raindrop impact, and influence soil surface properties such as bulk density, organic matter content, and aggregation (Osborn 1954, Copeland 1963, Blackburn 1975, Meeuwig and Packer 1976, Blackburn et al. 1982).

Research has generally shown interill erosion to increase as vegetation cover declines (Klemmedson 1956, Johnston 1962, Whitman et al. 1965, Smith 1967, Rauzi et al. 1968, Brown and Schuster 1969, McCalla et al. 1984b). Likewise, as soil bulk density increases, and organic matter content and aggregate stability decrease, erosion increases (Klemmedson 1956, Rhoades et al. 1964 Meeuwig 1970). Therefore, grazing management strategies that enhance vegetation cover, reduce soil bulk density, and increase soil organic matter and aggregate stability, tend to enhance watershed conditions.

Renner (1936) found the degree of erosion on the Boise River watershed in Idaho was correlated with grazing intensity, with low intensity having some effect on erosion. Barnes et al. (1939) attributed overgrazing of the Morena drainage basin in southern California as the major cause of accelerated erosion. Dunford (1949) concluded that erosion from a pine-bunchgrass region of Colorado was not significantly changed by moderate grazing (33\% herbage removal), but heavy grazing ( $57 \%$ herbage removal) doubled the normal amount of erosion compared to that of no grazing. On fescue (Festuca, spp. L.) rangeland in Saskatchewan, wet clay loam soil, Johnston (1962) found soil losses were not serious under light, moderate, or heavy rates of grazing. On continuously grazed rangeland, sediment production usually increases as animal stocking rate increases (Rhoades et al. 1964, Hanson et al. 1970).

Smith (1967), working in a ponderosa pine- (Pintus ponderosa Laws.) spike burgrass (Tragus berteroniamus Schult.) community in Colorado, found that erosion on heavily-grazed range sites was 8 times the rate of an exclosure and about 4 times that of light or moderately-grazed pastures. Menzel et al. (1978) studied erosion at the South Central Agricultural Research Station near Chickasha, Okla., for a period of 10 years, dealing with moderately-stocked rotational grazing and continuously-grazed pastures in the same watershed. They found sediment loss was 0.03 and $8.1 \mathrm{t} \mathrm{ha}^{-1}$ on rotationally-grazed and continuously-grazed pastures, respectively.

Mismanagement of domestic livestock, especially through excessive stocking rates, has caused severe degradation of the world's rangelands (Bentley 1898, Box 1967, Dregne 1978). 
Moderate stocking rates designed to use about half the current year's forage production are generally accepted as proper grazing management (Stoddart et al. 1975), but the take-half-and-leavehalf practice has several problems, especially in areas with great variation in precipitation and subsequent forage production. It is not unusual for a range to produce a few hundred kilograms per hectare I year and several times that much another year. In such a situation, the take-half-and-leave-half concept may not be an intelligent management decision because the half that is left may not be sufficient in dry years. The half left in wet years may be more than is needed for protection. which results in unused forage.

Most research with rotational grazing systems have shown that heavy stocking rates increase sediment production, regardless of the systems used (Blackburn 1984, Gamougoun et al. 1984, McCalla et al. 1984a,b, Pearson et al. 1975, Pluhar 1984, Smith 1980, Thurow 1985, Warren et al. 1986, Weltz 1983). Even at moderate stocking rates, rotational grazing systems have no consistent advantage over continuous grazing (Blackburn 1984, Blackburn et al. 1980, Knight 1980. Mbakaya 1985, McGinty et al. 1979, Wood 1980, Wood and Blackburn 1981, Wood et al. 1978). Heavy stocking rates under continuous grazing are almost universally deleterious to watershed condition, generally accelerating erosion (Alderfer and Robinson 1947, Blackburn 1984, Branson et al. 1981, Rauzi and Hanson 1966, Rhoades et al. 1964). Weltz and Wood (1986) found rotation grazing did not decrease erosion when heavy stocking rates were applied.

Someone must determine the amount of vegetation to be left after grazing to protect, maintain, and improve watershed condition. After determining values for many sites, modeling can provide useful values for other sites.

This experiment was conducted in a moist temperate region to determine the effects of different levels of residual phytomass on erosion. The main objective of the study was to determine an appropriate residual phytomass level for protecting the watershed by keeping erosion at a reasonably low level. The residual phytomass is assumed to be more important to erosion control than the percentage utilization of annual phytomass. It was hypothesized that various residual phytomass levels allowed significantly different levels of erosion because of the relationship of the phytomass to other factors like foliar and litter cover that influences the erosion process. The second objective was to determine suitable predictive equations of sediment concentration and total sediment loss.

\section{Study Area}

\section{Location}

The study was conducted at Lilawani Ranch near Alpuri in the sub-humid zone in northwestern Pakistan. The area lies between $34^{\circ} 31^{\prime}$ and $35^{\circ} 8^{\prime} \mathrm{N}$ latitude and $72^{\circ} 35^{\prime}$ and $73^{\circ} 1^{\prime} \mathrm{E}$ longitude. It is bounded on the northeast by the upper Indus Kohistan district; on the north and northwest by Malakand Agency, Swat and Swat Kohistan; on the south and southwest by Bunir subdivision, and on the southeast and east by the Indus River. The elevation varies from 450 to $4,500 \mathrm{~m}$, and land is mostly used for crops and grazing. Moderate to precipitous slopes exceeding $30 \%$ are normal. The surface configuration is generally rugged and uneven.

The entire area forms part of the Indus River watershed. The country's largest dam, the Tarbela, has been constructed on this river. Rapid sediment accumulation in this reservoir has reduced the original estimated life span of 120 years to 60 years. Cropping, deforestation, and overgrazing in the high elevations of the watershed created this accelerated erosion problem. The specific study site has been used for grazing as well as grass cutting to make hay. The same practice is common in the surrounding areas since the last century.

\section{Geology and Soils}

The study area is located in the mountainous region of the Swat Valley. The mountains are residual and colluvial primarily with plutonic and sedimentary exposed rocks. Mountainous soils are mostly loamy, contain a variable proportion of coarse rock fragments, and are shallow (bedrock within $1 \mathrm{~m}$ in depth). Generally, the surface soils are well humified, dark colored, and sufficiently base rich, structured, and thick enough to qualify as mollic epipedons. The epipedons are more pronounced in wetter and cooler locations. The organic matter content of the surface mineral horizons varies from about 1 to more that $9 \%$. Rangeland soils may contain more organic matter than their cultivated counterparts. Surface soils are weakly moderately granular, whereas subsoils are dominantly subangular blocky. Most of the soils are mollisols. The soils in the study area have been classified as Shangla series. Because they occur on sloping surfaces, these soils are subject to active water erosion, with intensity depending on the vegetation cover and the slope gradient.

\section{Climate}

The climate of the study area is sub-humid temperate. At nearby Besham, the average minimum temperature is in January $\left(6.7^{\circ} \mathrm{C}\right)$, and the average maximum temperature $\left(38.4^{\circ} \mathrm{C}\right)$ is in June. The mean minimum temperature during December and mean maximum temperature during June recorded at the Saidu Sharief Meteorological Station are $11.7^{\circ} \mathrm{C}$ and $37.7^{\circ} \mathrm{C}$. respectively.

Precipitation occurs both as rain and snow. The average annual precipitation is $960 \mathrm{~mm}$. Snowfall generally starts by the end of November on the higher peaks and descends in December and January. Streamflow is greatest during summer monsoon rains. Runoff is high and the watershed drains into the Indus River.

\section{Vegetation}

The study area falls in a pure blue pine (Pinus wallichian Wall.) zone between 1,677 to $2,440 \mathrm{~m}$ elevation. This zone is bounded by mixed silver fir (Abies pindrow Spash.) forests at higher elevation and pure chir pine (Pinus roxburghii Rox.) forests at lower elevations. Subdominant trees consist of walnut (Juglans regia Linn.), bird cherry (Prumus padus Linn.), Batangi (Pyrus pashia Ham.), amlook (Diospyros lotus Linn.), hill toon (Cedrela serrata Royle.), and horsechestnut (Aesculus indica Hiern.) at lower elevations. The undergrowth consist of kori (Berberis lycium Royle.), gangali gulab (Rosa moschata Mill.), shamshad (Buxus sempervirens Linn.), ghoraje (Indigofera pulchella Rox.), and chambali (Jasminum humile Linn.).

Grasses and forbs in the study area include lung ( $C$ ymbopogon iwarancusa Schult.), surmal (Heteropogon contortus Beauv.), pisholamae (Cenchrus ciliaris Linn.), changae (Aristida depressa Retz.), dadum (Sorghum halepense Pers.) and khabl ( $C_{\text {ynodon }}$ dactylon Pers.). 


\section{Methods}

Data were collected for 2 growing seasons, during summers of 1987 and 1988. A rainfall simulator described by Wilcox et al. (1986) was used to apply rainfall to 48 flexible circular plots, about $1 \mathrm{~m}^{2}$. A single stationary nozzle was placed $200 \mathrm{~cm}$ above the center of the plot, and the application rate was $12.7 \mathrm{~cm} \mathrm{hr}^{-1}$. The plots were constructed from metal sheets about $15 \mathrm{~cm}$ wide and $358 \mathrm{~cm}$ long. A small, metal runoff tray was connected to the plot to collect runoff. The soil was of such a nature that metal strips could easily be tamped into the soil without bending. The area of each plot was determined by a grid constructed from 1.2 $\mathrm{cm} \times 1.2 \mathrm{~cm}$ mesh. Simulated rainfall was applied to each plot at the existing or antecedent soil moisture level for $30 \mathrm{~min}$, and runoff collected and weighed (dry run). Plots were then covered with clear plastic to prevent evaporation and to ensure fairly uniform soil moisture conditions for the second rainfall application 20 to 24 hours later (wet run). Water was applied for $30 \mathrm{~min}$ during the wet run. Runoff from each plot was collected at $5 \mathrm{~min}$ intervals and weighed. A runoff sample was taken for sediment concentration at each 5-min interval.

Sediment was filtered off in the laboratory and dried at $105^{\circ} \mathrm{C}$ for 24 hours. The sediment was weighed in grams to determine concentration ( $\left.\mathrm{g} \mathrm{liter}^{-1}\right)$. Total sediment loss from each plot was calculated as runoff times sediment concentration summed over multiple time periods. Sediment for the wet runs were calculated in the same way.

Foliar and basal cover for each species within each plot were determined using a point sampling method (Pieper 1978). A total of 120 points were applied per plot for both foliar and basal cover, using a $100-\mathrm{cm}$ long metal frame with 20 vertical pins. Foliar cover was determined before plots were clipped, and basal cover after clipping the plots. Standing phytomass $\left(\mathrm{g} \mathrm{m}^{-2}\right)$ was determined for grasses and forbs by clipping to ground level. The litter was also hand collected. The phytomass material for each plot was placed in separate paper sacks, dried at 60 to $70^{\circ} \mathrm{C}$ for 48 hours, then weighed.

Antecedent soil moisture was calculated for the 0 to 5 and 5 to $10 \mathrm{~cm}$ depths by the gravimetric method. Samples were collected adjacent to the runoff plots before each simulated rainfall event. Bulk density was also determined at 0 to 3 and 5 to $8 \mathrm{~cm}$ depth before the second rainfall application by the core method (Black 1965). After the wet run, soil samples were taken from 0 to $10 \mathrm{~cm}$ depths for particle size and organic $\mathrm{C}$ analysis. Particle size distribution was estimated using the hydrometer method (Bouyoucos 1962). Organic $C$ percentage was estimated by the WalkleyBlack method (Black 1965). A micro-relief meter (Kincaid and Williams 1966) was used to determine soil surface roughness within each plot. Six readings ( 20 points each) of the micro-relief meter were taken per plot. Three readings were taken on the fall line and 3 readings perpendicular to the fall line. Average soil depth was also measured.

A homogenous area was subdivided into 8 plots. Within each plot, 6 subplots of $1 \mathrm{~m}$ square were randomly located. Because treatments were allotted to the various plots randomly and independently, the experimental design was a completely randomized design with subsampling with 4 treatments, 2 plots per treatment and 6 subplots per plot. The treatments were 4 different residual phytomass levels. In year 1 treatments $1,2,3$, and 4 had a residual phytomass of $2.667,1,432,1,020$ and $627 \mathrm{~kg} \mathrm{ha}^{-1}$ for treatments $1,2,3$, and 4 , respectively. Treatment 1 was not grazed and represented the potential phytomass each year. The remaining residual phytomass levels were achieved by allowing livestock to graze in the plots until the desired levels were achieved. The treatments were not equally spaced and, therefore, were considered non-structured.

The data for each year were analyzed separately. Overall differences among treatments were tested using analysis of variance by the GLM procedure (SAS Institute 1985). If the analysis of variance F-test was significant, then a protected Fisher's Least Significance Difference (LSD) was used to separate means at $0.01,0.05,0.1$ and 0.20 significance levels. Stepwise multiple regression was used to select vegetation and soil variables influencing interill erosion. Statistical analysis was also done to determine linear, quadratic and cubic effects.

\section{Results and Discussion}

During the first year, natural rainfall was less than the longterm average, resulting in the low phytomass production of 2,667 $\mathrm{kg} \mathrm{ha}^{-1}$ as compared to the second year of $3,382 \mathrm{~kg} \mathrm{ha}^{-1}$. The rainfall during year 2 was equal to average rainfall for the area. The remaining residual levels were similar in both years. Table 1 shows the potential phytomass of both years and the various residual phytomass levels achieved after grazing. Although the percentages of total phytomass are different, the residual levels are nearly the same in both years, except for the control. These levels were chosen because they generally represent moderate, heavy and very heavy grazing

\section{Mean Sediment Concentration}

In year 1 sediment concentration was significantly different between treatments at an observed significance level of 0.139 for antecedent soil moisture, and $\mathbf{0 . 0 2 6}$ for the soil moisture near field capacity. During year 2, the p-values were 0.077 and 0.016 for antecedent soil moisture and near field capacity. Mean sediment concentration was highest in treatment 4 and lowest in treatment 1 . The highest sediment concentration in treatment 4 resulted from the low residual phytomass level as shown in Tables 2 and 3. This difference was attributed to less protective cover for the soil.

In year 2 , the residual phytomass was greater than year 1 ; therefore, the difference in the mean sediment concentration between treatment 1 and the remaining treatment was greater. The difference among the remaining treatments was small. This shows the strong relationship between phytomass and sediment concentration. Linear, quadratic and cubic effects were tested,

Table 1. Total and percentage residual phytomass remaining on grazed and ungrazed plots during low and average rainfall years.

\begin{tabular}{cccccc}
\hline & \multicolumn{2}{c}{ Year 1} & & \multicolumn{2}{c}{ Year2 } \\
\cline { 2 - 3 } \cline { 5 - 6 } Treatment & Phytomass & $\begin{array}{c}\text { Percentage } \\
\text { of total }\end{array}$ & & Phytomass & $\begin{array}{c}\text { Percentage } \\
\text { of total }\end{array}$ \\
\hline & $\left(\mathrm{kg} \mathrm{ha}^{-1}\right)$ & $(\%)$ & & $\left(\mathrm{kg} \mathrm{ha}^{-1}\right)$ & $(\%)$ \\
1 & $2667(8)^{1}$ & 100 & $3382(18)$ & 100 \\
2 & $1432(10)$ & 54 & $1443(6)$ & 43 \\
3 & $1020(4)$ & 38 & $1037(3)$ & 31 \\
4 & $627(5)$ & 24 & $620(3)$ & 18 \\
\hline
\end{tabular}

IStandard error (SE) is given in the parenthesis for the phy tomass. 
Table 2. Treatment comparisons for mean sediment concenatration at the antecedent soil moisture level and near field capacity for year 1.

\begin{tabular}{|c|c|c|c|c|c|c|}
\hline \multirow{2}{*}{$\begin{array}{l}\text { Treat- } \\
\text { ment }\end{array}$} & \multirow[b]{2}{*}{ Phytomass } & \multirow{2}{*}{$\begin{array}{l}\text { Sediment } \\
\text { concentration }\end{array}$} & \multicolumn{4}{|c|}{ Level of significance ${ }^{1}$} \\
\hline & & & 0.01 & 0.05 & 0.10 & 0.20 \\
\hline \multicolumn{7}{|c|}{$\left(\mathrm{kg} \mathrm{hi} \mathrm{u}^{-1}\right) \quad\left(\mathrm{g}\right.$ litter $\left.{ }^{-1}\right)$} \\
\hline \multicolumn{7}{|c|}{ A. Antecedent soil moisture? } \\
\hline 1 & 2667 & 0.63 & $\mathbf{a}$ & b & b & c \\
\hline 2 & 1432 & 0.84 & $a$ & $a b$ & $a b$ & $\mathrm{bc}$ \\
\hline 3 & 1020 & 0.97 & $\mathbf{a}$ & $a b$ & $a b$ & $a b$ \\
\hline 4 & 627 & 1.16 & a & $\mathfrak{a}$ & $\mathbf{a}$ & $\mathbf{a}$ \\
\hline \multicolumn{7}{|c|}{ B. Soil moisture near field capacity ${ }^{3}$} \\
\hline 1 & 2667 & 0.58 & b & $\mathfrak{c}$ & b & c \\
\hline 2 & $1+32$ & 0.61 & $a b$ & $b c$ & b & c \\
\hline 3 & 1020 & 0.82 & $a b$ & $a b$ & a & b \\
\hline 4 & 627 & 0.97 & a & a & a & $\mathbf{a}$ \\
\hline
\end{tabular}

Means followed by the same letter within a soul monture condition are not signilicantly ditferent.

2Overall analyss of variance $F(3,4)=3.30, p=0139$ for dry nun.

Ooverall analysis of variance $F(3,4)=9.69, p=0.026$ for wet run.

and only linear and quadratic effects were found significant at the 0.10 significance level.

\section{Total Sediment Loss}

In year 1 antecedent soil moisture, there was a significant difference between treatments at a p-value of 0.098 . The p-value was 0.003 for the wet run. During year 2 , these p-values were 0.008 for the dry run and 0.014 for the wet run.

The total sediment loss was highest in treatment 4 and lowest in treatment 1 (exclosure) as shown in Tables 4 and 5 . The highest sediment loss in treatment 4 resulted from high runoff and high sediment concentration. The runoff and sediment concentration have been affected by the lowest residual phytomass level. The difference in sediment yield was attributed to the various residual phytomass levels. Treatment 1 had the highest residual phytomass and the least bare ground $(5.8 \%)$ while treatment 4 had the least residual phytomass level and most bare ground (59.5\%). In treatment 4 , because of reduced soil surface protection, a large percentage of area was opened to raindrop impact.

Only the linear and quadratic effects were found significant at the 0.10 significance level.

Table 3. Treatment comparisons for mean sediment concentration at the antecedent soil moisture level and near field capacity for year 2.

\begin{tabular}{|c|c|c|c|c|c|c|}
\hline \multirow{2}{*}{$\begin{array}{l}\text { Treat- } \\
\text { ment }\end{array}$} & \multirow[b]{2}{*}{ Phytomass } & \multirow{2}{*}{$\begin{array}{l}\text { Sediment } \\
\text { concentration }\end{array}$} & \multicolumn{4}{|c|}{ Level of significance $^{l}$} \\
\hline & & & 0.01 & 0.05 & 0.10 & 0.20 \\
\hline \multicolumn{7}{|c|}{$\left(\mathrm{kgha}^{-1}\right) \quad\left(\mathrm{g}\right.$ litter $\left.r^{-1}\right)$} \\
\hline \multicolumn{7}{|c|}{ A. Antecedent soil moisture ${ }^{2}$} \\
\hline 1 & 3382 & 1.05 & & b & & \\
\hline 2 & 1443 & 1.35 & a & $a b$ & $\mathbf{a}$ & a \\
\hline 3 & 1037 & 1.44 & a & a & $\mathbf{a}$ & a \\
\hline 4 & 620 & 1.55 & $a$ & $\mathbf{a}$ & a & a \\
\hline \multicolumn{7}{|c|}{ B. Soil moisture near field capacity ${ }^{3}$} \\
\hline l & 3382 & 0.58 & b & b & b & b \\
\hline 2 & 1443 & 0.89 & $\mathrm{a}$ & a & a & a \\
\hline 3 & 1037 & 0.90 & a & a & $\mathbf{a}$ & a \\
\hline 4 & 620 & 0.93 & a & $\mathbf{a}$ & a & a \\
\hline
\end{tabular}

Table 4. Treatment comparisons for total sediment loss at the antecedent soil moisture level and near field capacity for year 1.

\begin{tabular}{|c|c|c|c|c|c|c|}
\hline \multirow{2}{*}{$\begin{array}{l}\text { Treat- } \\
\text { ment }\end{array}$} & \multirow[b]{2}{*}{ Phytomass } & \multirow{2}{*}{$\begin{array}{l}\text { Sediment } \\
\text { concentration }\end{array}$} & \multicolumn{3}{|c|}{ Level of significancel } & \multirow[b]{2}{*}{0.20} \\
\hline & & & 0.01 & 0.05 & 0.10 & \\
\hline & $\left(\mathrm{kg} \mathrm{ha}^{* 1}\right)$ & (g litter $\left.{ }^{-1}\right)$ & & & & \\
\hline \multicolumn{7}{|c|}{ A. Antecedent soil moisture 2} \\
\hline 1 & 2667 & 2.77 & $\mathbf{a}$ & b & b & c \\
\hline 2 & 1432 & 4.65 & a & $a b$ & b & bc \\
\hline 3 & 1020 & 5.67 & $\mathbf{a}$ & $a b$ & $a b$ & $a b$ \\
\hline 4 & 627 & 7.68 & $\mathbf{a}$ & a & $\mathbf{a}$ & a \\
\hline \multicolumn{7}{|c|}{ B. Soil moisture near field capacity ${ }^{3}$} \\
\hline 1 & 2667 & 3.04 & c & $c$ & $\mathfrak{c}$ & d \\
\hline 2 & 1432 & 3.86 & $\mathrm{bc}$ & $b c$ & c & c \\
\hline 3 & 1020 & 5.03 & b & b & b & $b$ \\
\hline 4 & 627 & 7.07 & $a$ & $\mathbf{a}$ & $\mathbf{a}$ & $\mathbf{a}$ \\
\hline
\end{tabular}

Means followed by the same letter within a soil moisture condition are not significantly different.

2Overall analysis of variance $F(3,4)=4.24, p=0.098$ for $\mathrm{dry}$ run.

${ }^{3}$ Overall analysis of variance $F(3,4)=32.94 . p=0.003$ for wet run.

\section{Predictive Equations}

The regression equations are of the following general form:

$$
\hat{Y}=a+b l X 1+\ldots \ldots . . . b n X n
$$

where $\hat{Y}$ is the predicted dependent variable, $a$ is the $y$-intercept, $b$ is the estimated regression coefficient, and $\mathrm{X}$ is the independent variable influencing $\hat{\mathrm{Y}}$. With the help of these equations, various dependent variables can be predicted for the study sites and can also be used for sinilar sites in the area. The predictive equations also identify the most important variables influencing a given dependent variable. Four predictive equations were developed for each dependent variable by combining data for year 1 and year 2 . A significance level of 0.15 was chosen for an independent variable to be included in the model. The regression equations are shown in Tables 6 and 7.

\section{Sediment Concentration}

Sediment concentration is affected by a number of independent variables; therefore, it is important to know which of these variables were included in the final model. Sediment concentration also affects the total sediment loss.

The predictive equation for mean sediment concentration at

Table 5. Treatment comparisons for total sediment loss at the antecedent soil moisture level and near field capacity for year 2.

\begin{tabular}{|c|c|c|c|c|c|c|}
\hline \multirow{2}{*}{$\begin{array}{l}\text { Treat- } \\
\text { ment }\end{array}$} & \multirow[b]{2}{*}{ Phytomass } & \multirow{2}{*}{$\begin{array}{l}\text { Sediment } \\
\text { concentration }\end{array}$} & \multicolumn{3}{|c|}{ Level of significance } & \multirow[b]{2}{*}{0.20} \\
\hline & & & 0.01 & 0.05 & 0.10 & \\
\hline \multicolumn{7}{|c|}{$\left(\mathrm{kg} \mathrm{ha}^{-1}\right) \quad\left(g\right.$ litter $\left.^{-1}\right)$} \\
\hline \multicolumn{7}{|c|}{ A. Antecedent soil moisture? } \\
\hline 1 & 3382 & 3.94 & b & c & c & d \\
\hline 2 & 1443 & 6.71 & $a b$ & b & b & $c$ \\
\hline 3 & 1037 & 8.55 & a & $\mathrm{ab}$ & $a b$ & b \\
\hline 4 & 620 & 10.01 & $\mathbf{a}$ & $\mathbf{a}$ & $\mathbf{a}$ & $\mathbf{a}$ \\
\hline \multicolumn{7}{|c|}{ B. Soil moisture near field capacity ${ }^{3}$} \\
\hline 1 & 3382 & 2.49 & b & b & b & $\mathrm{c}$ \\
\hline 2 & 1443 & 5.15 & a & $\mathrm{ab}$ & $\mathbf{a}$ & $b$ \\
\hline 3 & 1037 & 5.79 & a & $\mathbf{a}$ & $\mathbf{a}$ & $a b$ \\
\hline 4 & 620 & 6.34 & $\mathbf{a}$ & $\mathbf{a}$ & $\mathbf{a}$ & $\mathbf{a}$ \\
\hline
\end{tabular}


Table 6. Multiple regression equations for mean sediment concentration for year 1 and year 2 with combined soil moisture conditions.

\begin{tabular}{|c|c|c|c|c|c|c|}
\hline $\begin{array}{l}\text { Year and } \\
\text { condition }\end{array}$ & & sion & & & & $\mathrm{R}^{2}$ \\
\hline $\begin{array}{l}1987 \text { and } \\
1988 \text { dry }\end{array}$ & $\begin{aligned} \hat{Y} 1=09.52- & 0.002(\times 1) \\
& \left(\mathrm{se}^{1}=00005\right) \\
& (\mathrm{p}=0.008)\end{aligned}$ & + & $\begin{array}{l}0.024(\mathrm{X} 13) \\
(\mathrm{se}=0.004) \\
(p=0.0001)\end{array}$ & & & 0.32 \\
\hline $\begin{array}{l}1987 \text { and } \\
1988 \text { wet }^{3}\end{array}$ & $\begin{array}{r}\hat{\mathrm{Y}}^{2}=0.784-0.001(\mathrm{X} 1) \\
(\mathrm{se}=0.0003) \\
(\mathrm{p}=0.0002)\end{array}$ & $=$ & $\begin{array}{l}0.003(X 5) \\
(\mathrm{se}=0.002) \\
(\mathrm{p}=0.098)\end{array}$ & + & $\begin{array}{l}0.0007(X 14) \\
(s e=0.003 \\
(p=0.008)\end{array}$ & 0.35 \\
\hline
\end{tabular}

Sumple size $(n)=96$

IStuntard error (se) and p-salue for each regressun coefictent have been given in parenthesis for each column respectively.

$\mathrm{X}^{2} \mathrm{l}=$ Stunding phytomass $\left(\mathrm{g}^{2}\right)$

$x 5=$ Bare ground whociated with foliar cover (5)

$X 13=$ Sol noisture $\left(5-10 \mathrm{~cm}\right.$ depth) $\mathrm{dry}^{(5)}$

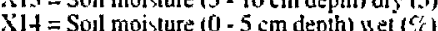

-Oserall andy ss of bariance $F(2,78)=18.57, p=0$ onol tor year 1 and year 2 , dry.

${ }^{3}$ Overall andly $4>$ of variance $F(3,76)=13.61, p=0001$ Ior year 1 and year 2 , wet.

antecedent soil moisture for the combined data of year I and year 2 (Table 6) contained standing phytomass (X1) and soil moisture from 5 to $10 \mathrm{~cm}$ depth dry (X13). Both these variables are important in affecting sediment concentration.

The predictive equation for mean sediment concentration with soil moisture near field capacity for the combined data of year 1 and year 2 (Table 6 ) included standing phytomass (X1), bare ground associated with foliar cover (X5) and soil moisture from 0 to $5 \mathrm{~cm}$ depth (X14).

\section{Total Sediment Loss}

Total sediment loss is greatly affected by runoff rates, and protective ground cover, in turn, affects runoff. In watershed management, the resource manager is often concerned about the rate of soil loss on a given range site. The manager may also be interested in knowing the various factors that greatly affect total sediment loss. Development of a suitable predictive model will help in identifying the important variables.

The predictive equation for total sediment loss at antecedent soil moisture for the combined data of years 1 and 2 (Table 7) contained standing phytomass (X1), foliar cover (X3), bare ground associated with foliar cover (X5) and soil moisture from 5 to $10 \mathrm{~cm}$ depth (X13).

The predictive equation for total sediment loss at soil moisture near field capacity for the combined data of year 1 and year 2 (Table 7) included standing phytomass (X1) and bare ground associated with foliar cover (X5).

Like many other parts of the world, most Pakistan rangelands are grazed heavily. Overgrazed rangelands not only affect on-site productivity, but also markedly affect runoff quality and sedimentation of reservoirs. In Pakistan, moist temperate rangelands are under heavy grazing pressure by local livestock and nomadic herds. The main reason for the deterioration is the lack of knowledge and poor socioeconomic condition of the people, which lead to overgrazing. To reduce erosion people must manage for a suitable residual phytomass level, which has a direct effect on these processes. Although the exclosure (treatment 1 ) resulted in the lowest sediment loss and is also most desirable from a watershed point of view, these people can not afford $100 \%$ protection of the phytomass. On the other hand, the other phytomass levels resulted in higher sediment loss and may not be desirable for watershed protection. Thus, the land manager is left with treatments 2,3 . and 4 from which to choose the residual phytomass level that will ensure proper utilization of the resource and proper protection of the watershed condition.

The choice for a given treatment will vary from site to site, and is greatly dependent on the major management objectives. If a range site is situated in a greatly disturbed and important riparian

Table 7. Multiple regression equations for mean sediment concentration for year 1 and year 2 with combined soil moisture conditions.

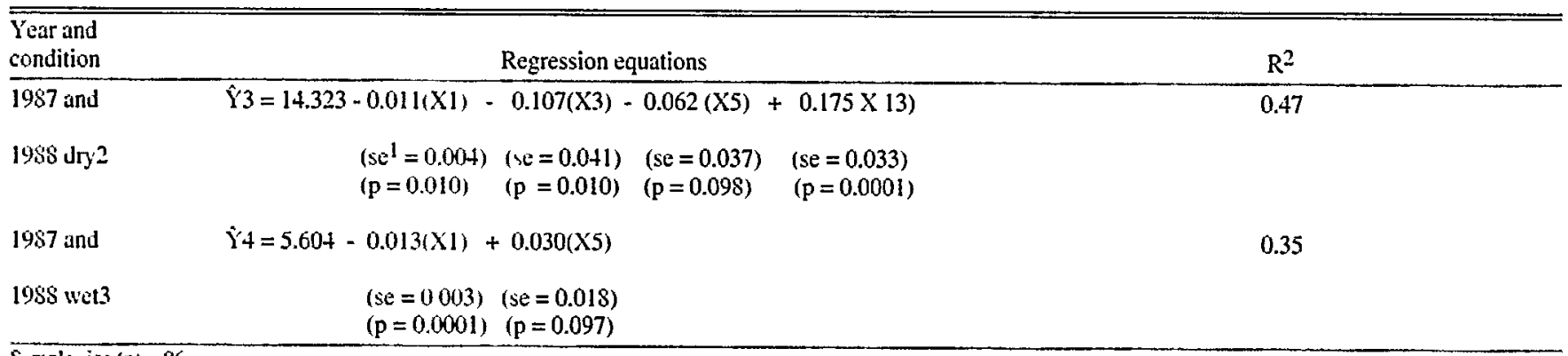

Sumple size $(n)=96$

IStundard error (xe) and p-talue for each regresson coefficient have been given in parenthesis for each column respectively.

$\mathrm{X} 1=$ Standing phy tomas $\left(\mathrm{g} \mathrm{m}^{2}\right)$

$X_{2}=$ Litter phytomas:

$x^{3}=$ Foliar cover $(G)$

XS = Bare ground associated with foliar cover (5)

$X_{1}=$ Soil monsure $(0-5 \mathrm{~cm}$ depth) dry $(c)$

$x_{13}=$ Soll moisture $(5-10 \mathrm{~cm}$ depth) dry (5)

2Oterall analy's is of variance $F(4.81)=18.17 . p=00001$ for year 1 and year 2, dry.

${ }^{3}$ Orerall anilysis of variance $F(2,82)=22.59, p=0001$ ior year 1 and year 2 , wet. 
area, treatment 1 may be recommended for quick restoration. Similarly, if the range condition is not low and there is great temporary demand for forage, treatment 4 can also be recommended. In our view, the best choice would be treatment 2 or 3 , rather than choosing the extremes.

The following conclusions are drawn from the results of this study: 1) Residual phytomass levels significantly affect sediment concentration and total sediment loss, 2) The exclosure resulted in the lowest sediment production among all treatments, 3) The treatment with the lowest residual phytomass resulted in the highest sediment loss, 4) Standing phytomass was the most important variable, followed by foliar and basal cover, which greatly affect sediment production, 5) The potential phytomass changes from year to year; therefore, the watershed manager should rely on the residual phytomass level rather than removing a fixed percentage of forage.

In general, the increased sediment concentration and total sediment loss indicate treatment $4\left(620\right.$ to $\left.627 \mathrm{~kg} \mathrm{ha}^{-1}\right)$ was the least desirable condition of any of the grazing treatments, followed by treatments 3 and 2 . Treatment $1\left(2,667\right.$ to $\left.3,382 \mathrm{~kg} \mathrm{ha}^{-1}\right)$ has the most desirable condition from a watershed point of view, but not for livestock production.

\section{Literature Cited}

Alderfer, R.B. and R.R. Robinsin. 1947. Runoff from pastures in relation to grazing intensity and soil compaction. Amer. Soc. Agron. J. 29:948-958.

Barnes, F.E., C.J. Krabel, and R.S. LaMlotle. 1939. Effects of accelerated erosion on silting on Morena Reservoir, San Diego County, California. U.S. Dep. Agr. Tech. Bull. 639.

Bentley, H.L. 1898. Cattle ranges of the Southwest: A history of exhaustion of pasturage and suggestions for its restoration. USDA Farmers Bull. 72.

Black, C.A. 1965. Methods of soil analy'sis. Amer. Soc. Agron. Series 9. Madison, Wis.

Blackburn, W.H. 1975. Factors influencing infiltration and sediment production of semiarid rangelands in Nevada. Water Resource Res. 11:929-937.

Blackburn, W.H. 1984. Impacts of grazing intensity and specialized grazing systems on watershed characteristics and responses, p. 927993. In: Developing strategies for rangeliand management. Nat. Res. Council/Nat. Acad. Sci. Westview Press, Boulder, Colo.

Blackburn, W.H., R.W. Knight, and M.K. Wood. 1982. Impacts of grazing on watersheds. Texas Agr. Exp. Station. MP 1496.

Blackburn, W.H., R.W. Knight, M.K. Wood, and L.B. Merrill. 1980. Watershed parameters as influenced by grazing, p. 552-575. In: Proc. of the Symp. on Watershed Manage. p. 552. Amer. Soc. Civil Eng., Boise. Ida.

Bouyoucos, G.J. 1962. Hydrometer method improved for making particle size analysis of soil. Agron. J. 54:464-465.

Boy, T.W. 1967. Range deterioration in west Texas. Southwestern Historical Quart. 9:37-45.

Branson, F.A., G.F. Gifford, K.G. Renard, and R.F. Hadley. 1981. Range hydrology. Range Sci. Ser. No. 1 Kendall/Hunt Pub. Co., Dubuque, La.

Brown, J.W. and J.L. Schuster. 1969. Effects of grazing on a hard land site in the Southern High Plains. J. Range Manage. 22:418-423.

Copeland, O.L., Jr. 1963. Land use and ecological factors in relation to sediment yielus. In: Proc., Fed. Interagency Sedimentation Conf., USDA Misc. Pub. 980:72-84.

Dregne, H.E. 1978. Desertification: Minn's abuse of the land. J. Soil and Water Conserv. 33:11-14.
Dunford, E.G. 1949. Relation of grazing to runaff and erosion on bunchgrass ranges. USDA For. Serv., Rocky Mt. For. and Range Exp. Sta. Res. Note 7.

Gamougoun, N.D., R.P. Smith, M.K. Wood, and R.D. Pieper. 1984. Soil, vegetation, and hydrologic responses to grazing management at Fort Stanton, New Mexico. J. Range Manage. 37:538-541.

Hanson, C.L., A.R. Kuhlman, C.J. Erickson, and J.K. Lewis. 1970. Grazing effects on runoff and vegetation on western South Dakota rangeland. J. Range Manage. 23:418-420.

Johnston, A. 1962. Effects of grazing intensity and cover on waterintake rate of fescue rangeland. J. Range Manage. 15:79-82.

Kincaid, D.R. and G. Williams. 1966. Rainfall effects on surface characteristics following range improvement treatments. J. Range Manage. 19:346-351.

Klemmedson, J.O. 1956. Interrelations of vegetation, soils, and range conditions induced by grazing. J. Range Manage. 9:134-138.

Knight, R.W. 1980. Hydrologic response of selected grazing systems on the Edward Plateau. Ph.D. Diss., Texas A\&M Univ., College Station, Tex.

Mbakaya, D.S. 1985. Grazing systems effects on infiltration rates and sediment production of a bushed grassland, Buchuma, Kenya. M.S. Thesis. Texas A\&M Univ., College Station, Tex.

McCalla, G.R., W.H. Blackburn, and L.B. Merrill. 1984a. Effects of livestock grazing on infiltration rates, Edwards Plateau of Texas. J. Range Manage. 37:265-268.

McCalla, G.R., W.H. Blackburn, and L.B. Merrill. 1984b. Influence of soil, vegetation, and grazing management on infiltration rates and sediment production, Edwards Plateau of Texas. J. Range Manage. 24:198-200.

McGinty, W.A., F.E. Smeins, and L.B. Merrill. 1979. Influence of soil, vegetation, and grazing management on infiltration rate and sediment production Edwards Plateau rangeland. J. Range Manage. 32:33-37.

Meeuwig, R.O. 1970. Sheet erosion on intermountain summer ranges. USDA Forest Ser., Intermountain Forest and Range Exp. Sta. Res. Paper Int-85.

Meeuwig, R.O. and P.E. Packer. 1976. Erosion and runoff on forest and rangelands. p. 106-116. In: Proc. of the Fifth Workshop of the United States/Australia Rangelands Panel, Boise, Ida.. June 15-22. 1975.

Menzel, R.G., E.D. Rhoades, A.E. Olnes, and S.J. Smith. 1978. Variability of annual nutrient and sediment discharges in runoff from Oklahoma cropland and rangeland. J. Environ. Qual. 7:401-406.

Osborn, B. 1954. Soil splash by raindrop impact on bare soils. J. Soil and Water Conser. 9:33-38.

Pearson, G.A., G.A. Jung, R.E. Fowler, and D.M. Mitchell. 1975. Effects of grazing on infiltration rates and waste water spray field. Proc. Soil Soc. Amer. 29:954-957.

Pieper, R.D. 1978. Measurement techniques for herbaceous and shrubby vegetation. New Mexico State University, Las Cruces, N.M.

Pluhar, J.J. 1984. Hydrologic impacts of selected grazing systems on the Texas Rolling Plains. M.S. Thesis, Texas A\&M Univ., College Station, Tex.

Rauzi, F., C.L. Fly, and E.J.Dykesterhuis. 1968. Water intake on midcontinental rangelands as influenced by soil and plant cover. USDA, Tech. Buil. 1390.

Rauzi, F., and C.L. Hanson 1966. Water intake and runoff as affected by intensity of grazing. J. Range Manage. 19:351-356.

Renner, F.G. 1936. Conditions influencing erosion on Boise River watershed. USDA., Tech. Bull. 528.

Rhoades, E.P., L.F. Locke, H.M. Taylor, and E.H. Mcllvain 1964. Water intake on sandy range as affected by twenty years of differential cattle stocking rates. J. Range Manage. 17:185-190.

SAS Institute, Inc. 1985. SAS User's Guide: Statistics, Version 5 Edition, Cary, N.C.: SAS Institute, Inc., 1985.

Smith, D.R. 1967. Effects of cattle grazing on a ponderosa pine-bunchgrass range in Colorado. USDA, Tech. Bull. 1371.

Smith, R.P. 1980. The influence of different grazing practices on infiltration rates and sediment production at Fort Stanton, New Mexico. M.S. Thesis. New Mexico State Univ., Las Cruces, N.M. 
Stoddart, L.A., A.D. Smith, and T.W. Box. 1975. Range Management. McGraw-Hill Book Co., New York, N.Y.

Thurow, T.L. 1985. Hydrologic interrelationships with vegetation and soil as affected by selected livestock grazings and climate on the Edwards Plateau. Ph.D. Diss.. Texas A\&M Univ., College Station, Tex.

Warren, S.D., T.L. Thurow, W.H. Blackburn, and N.E. Garza. 1986. The influence of livestock trampling under short-duration grazing on soil hydrologic characteristics. J. Range Manage. 39:491-495.

Weltz, M. 1983. The influence of short duration and continuous grazing on infiltration rates and sediment yield in southeentral New Mexico. M.S. Thesis, New Mexico State Univ ${ }_{n}$ Las Cruces, N.M.

Weltz, M., and M.K. Wood. 1986. Short duration grazing in central New Mexico: Effects on sediment production. J. Soil and Water Conser. 41:262-266.

Whitman, W.C., D. Zeller, and A.J. Bjugstad. 1965. Grazing effects cover-reduces soil water intake. Crops and Soils 17:23-24.
Wilcox, B.P., M.K. Wood, J.T. Tromble, and T.J. Ward. 1986. A hand portable single nozzle rainfall simulator designed for use on steep slopes. J. Range Manage. 39:375-377.

Wood, M.K., W.H. Blackburn, F.E. Smeins, and W.A. McGinty. 1978. Hydrologic impacts of grazing systems, p. 288-291. In: Proceedings of the First Internat. Range Congr. Soc. Range Manage., Denver, Colo.

Wood, M.K. 1980. Inpacts of grazing systems un watershed values, p. 163-170. In: K.C. McDaniel and C. Allison (EDs.)., Grazing Management Systems for Southwest Rangelands. New Mexico State Univ., Las Cruces, N.M.

Wood, M.K., and W.H. Blackburn. 1981. Grazing Systems: Their influences on infiltration rates in the rolling plains of Texas. J. Range Manage. 34:331-335. 